QUADERNS DE FILOSOFIA VOL. VI NÚM. 2 (20I9): 63-87

eISSN: 234I-3042 DOI: I 0.7203/QFIA. 6.2.I I 406

Francisco Fandos Marí ${ }^{1}$

Universidad Nacional de Educación a Distancia (UNED)

\title{
¿Tiene cabida el justiciero en las sociedades democráticas? Una respuesta desde el mundo del cómic
}

Received: 23/1/18. Accepted: 3/2/19

Resumen: En el presente artículo se reflexionará en torno a la figura del justiciero y su posible encaje en las actuales sociedades democráticas. Se abordará la relación de incompatibilidad entre la idea del Estado legitimado para el uso de la violencia y la figura del justiciero. Cómo desde el mundo del cómic ha sido representado no como un defensor de la justicia sino como alguien que actúa al margen de la ley.

Abstract: The following article will propose a reflection about the figure of the avenger and how he could fit into current democratic societies. Also, the relation of incompatibility between the legitimation of the State for using the violence and the role of this kind of avenger will be addressed. How from superhero's comic-books an avenger has been represented not as a defender of justice but as someone that acts on the fringes of the law.

Palabras clave: justiciero, democracia, legitimación, justicia, héroe, cómic.

Keywords: avenger, democracy, legitimation, justice, hero, comic.

\section{INTRODUCCIÓN}

$\mathrm{B}$ ajo la antropológicamente pesimista (¿o realista?) visión de Hobbes, en un estado de guerra de todos contra todos surge la imperiosa necesidad de generar un pacto en el que se garanticen unas mínimas condiciones

${ }^{1}$ Contacto: fanditos@hotmail.com. 
de conservación de paz y seguridad en la ciudadanía ${ }^{2}$. El problema surge ante el precio que se haya de pagar por la consecución de dicho objetivo de paz y seguridad.

Uno de los múltiples retos para la difícil convivencia entre iguales reside en los responsables de generar dicho pacto. Fruto de ese pacto es el Estado, donde se tendrán que buscar los equilibrios en torno a las naturales necesidades y deseos individuales con el denominado bien común en el marco y los límites de la legitimidad que procura un régimen democrático. Dicho equilibrio resulta fundamental para evitar una figura que, lejos de encarnar las mejores de las virtudes en un gobernante, se convierta en una suerte de referente contrario al sistema con más sombras que luces en el desempeño de su tarea o "misión salvífica": el justiciero; polémico y ambiguo en su interpretación de la justicia.

Como plantea Raymond Aron en la introducción a la obra El político y el cientifico de Max Weber, "la moral del hombre de acción es ciertamente la moral de la responsabilidad"3. La responsabilidad en el desempeño de su labor debe ser un valor esencial para lograr el éxito en este cometido sin dejar de lado la vigilancia a los derechos fundamentales. ¿Quién podría llevar a cabo tal empresa? En el siguiente artículo se reflexionará acerca de esta cuestión bajo una óptica filosófica pero ligada también a la representación que del héroe se ofrece desde el mundo del cómic. De este modo se presentará un marco teórico y su posterior reflejo en el ámbito del cómic de superhéroes para ofrecer una posible solución al planteamiento que da lugar al título de esta reflexión, esto es; si un justiciero tiene cabida en las sociedades democráticas. Esta idea servirá como hilo conductor pues la tesis central es que un justiciero no es un héroe y por tanto no tiene razón de ser en una democracia.

En primer lugar, se tratarán de acotar adecuadamente una serie de términos ligados al a veces confuso y ambiguo lenguaje jurídico para sostener una base teórica a partir de la cual pudiese dar sentido a alguien ajeno al poder legítimamente establecido. A partir de ahí, se abordará la cuestión acerca de qué pueda motivar la aparición de una figura alternativa al sobrentendido garante de la convivencia pacífica y democrática en un Estado.

A continuación, siguiendo a Weber, se analizará la figura del líder carismático y su posible analogía con el justiciero; alguien que se configura como un líder carismático ad hoc y cuyo proceder, sobrepasando la legalidad, es autolegitimado sobre la base de ese pretendido carisma. Además, se reflexionará sobre la posible perversión de justificar la aparición del justiciero cuando el sistema garante de nuestras libertades puede fallar o quedar en entredicho.

${ }^{2}$ Hoвbes, Thomas, Leviatán, cap. XIII, Madrid: Ed. Sarpe, 1983, p. 176.

${ }^{3}$ Weber, Max, El politico y el cientifico, Madrid: Alianza Editorial, 2015, p. 36. 
Delimitar el rol del héroe será básico para diferenciarlo de su contrapunto, el justiciero (que no el villano ${ }^{4}$ ) y valorar cómo el actuar de cada uno de ellos es muy distinto así como también lo es la consideración ética de sus actos.

También habrá que buscar en la justificación del justiciero la dicotomía no resuelta que contrapone los valores de libertad y seguridad y que el mundo del cómic ha sabido representar tan acertadamente. Seguidamente, desde la perspectiva del universo cinematográfico y las viñetas del cómic de superhéroes, se contrapondrán los modelos del héroe y del justiciero para señalar la idoneidad de uno frente al otro en un modelo social democrático.

Finalmente a modo de epílogo, se valorará de nuevo la tesis central sostenida en el artículo; que un justiciero no puede ser un héroe. Se recalcará la idea de la inadecuación de un justiciero en una democracia. Yendo incluso más allá, se cuestionará la conveniencia de un "héroe" que, aun estando dentro de los límites de la ley, se alce como una suerte de autoridad moral por encima de los individuos de su propia comunidad. Bajo esta óptica, más que plantear la dicotomía justiciero-héroe, se dejará la puerta abierta a la reflexión sobre si es necesario un héroe con unas "cualidades especiales" por encima de aquel ciudadano anónimo y ordinario que desempeña su actividad cotidiana en el marco de la comunidad política en la que se inserta. En síntesis: si es deseable un estandarte moral; si son necesarios hoy los héroes y, en todo caso, qué clase de héroes.

\section{MARCO TEÓRICO: ¿OSTENTAR O DETENTAR EL PODER?}

El justiciero ha planteado no pocos interrogantes morales por su posible acomodo en el seno de una democracia. El punto de partida para abordar tales interrogantes serán las ideas que expone Max Weber en la conferencia pronunciada en invierno de 1919 sobre La política como vocación. En dicha conferencia se define al Estado como: "aquella comunidad humana que, dentro de un determinado territorio (el territorio es el elemento distintivo), reclama (con éxito) para sí el monopolio de la violencia física legítima". ${ }^{5}$ En virtud de esta definición, el justiciero queda excluido de este modelo de Estado. Por lo tanto, siempre y cuando éste cumpla con su misión de garante del orden y las libertades públicas, nadie podrá justificar la necesidad de una figura al margen de lo establecido legítimamente.

${ }^{4}$ Un villano y un justiciero no tienen por qué ser equivalentes. El villano por definición es ruin e indigno y sus acciones siempre están orientadas al mal. El justiciero puede compartir los mismos objetivos y propósitos que el héroe aunque los medios que utilice no sean necesariamente los más idóneos.

${ }^{5}$ Weber, El politico y el científico, p. 83. 
Haciendo un análisis más minucioso de la citada frase, es esencial precisar debidamente los términos. El término ostentar hace referencia a "mostrar o hacer patente una cosa". ${ }^{6}$ En el caso que nos ocupa, el Estado hace patente efectivamente algo que le otorga el derecho a ciertas prerrogativas. Esto es, al uso de la violencia. Ese algo es la legitimidad para ejercer dicha prerrogativa. Por otro lado, detentar implica "retener y ejercer ilegítimamente algún poder o cargo público". 7 Una dictadura es un ejemplo de la detentación del poder. De lo anterior se puede colegir que, mientras exista legitimidad, el Estado podrá retener exclusivamente para sí tal derecho a esas ventajas.

Por lo que respecta a la idea de legitimidad, también se hace necesario puntualizar algunos aspectos para comprender bien el porqué de la aceptación de una norma en un momento determinado. La legitimidad alude a un reconocimiento. Dicho reconocimiento tiene una doble vertiente. Por un lado, un proceder conforme a la legalidad vigente. El ejercicio legítimo del poder radica en la elección democrática como respuesta de la voluntad general del pueblo y por tanto de la aceptación libre de unos representantes que puedan, llegado el caso, ostentar ese monopolio legítimo de la violencia. Es por tanto capital que las medidas que puedan derivarse de la actuación de estos representantes, se enmarquen en la más pura y nítida legalidad para que sean aceptadas sus consecuencias. Dicho de otro modo, para justificar que el monopolio de la violencia sea verdaderamente legítimo, no puede hallarse ni el más mínimo atisbo de ilegalidad en sus principios fundacionales. La cualidad de lo legítimo implica estar conforme con las leyes. Por ello, el monopolio del uso de la violencia tendrá un encaje en las sociedades democráticas mientras venga determinado por normas que justifiquen lícitamente dicho uso.

Pero ese reconocimiento, esa legitimidad a la que se alude, tiene otra vertiente. Además de la adecuación a la legalidad vigente dentro del modelo de Estado de Derecho en el que cabe enmarcarse, es necesario que exista una aceptación social de la norma. En la medida en que una norma sea justa, no parece que exista motivo alguno para desobedecer la ley. En ese sentido esta acepción de la legitimidad encierra un importante elemento de moralidad. No sirve por tanto que jurídicamente la norma sea impecable, que haya satisfecho todos los requisitos legales necesarios para su aprobación. Expresado más técnicamente, una norma es legítima no solo cuando es aceptada de iure sino también de facto. Y en múltiples ocasiones encontramos cómo el reconocimiento social muchas veces va a un ritmo distinto del reconocimiento legal. Por ejemplo, en España, la ley del divorcio se aprobó en el año 1981, y ob-

${ }^{6}$ DRAE, 21 a edición, tomo II, 1a entrada, Madrid: Editorial Espasa-Calpe, 1995, p. 1492.

${ }^{7}$ DRAE, $21^{\text {a }}$ edición, tomo I, 2a entrada, p. 737. 
viamente existían parejas que habían roto su proyecto de vida en común. En este sentido, el reconocimiento legal llega después del reconocimiento social.

En otras ocasiones, puede darse la circunstancia de que, pese a la existencia de un reconocimiento legal, no venga acompańado por un reconocimiento de la sociedad (o al menos parte de ella). Por ejemplo, la ley sobre protección de la seguridad ciudadana de 1992, llamada también ley Corcuera o "ley de la patada en la puerta", tuvo un reconocimiento legal, habida cuenta de que el gobierno de entonces (presidido por el PSOE de Felipe González) tenía la mayoría necesaria para aprobar la ley. Pese a ello, algunos elementos polémicos de dicha ley fueron llevados ante el Tribunal Constitucional por lo que no hubo un reconocimiento de, al menos, una parte de la sociedad. En la medida en que estas dos dimensiones del término legitimidad entran en conflicto, se podría estar favoreciendo consciente o inconscientemente la aparición de un justiciero. Aquel individuo que, por sus acciones, puede aspirar a ser aceptado social pero no legalmente. Una combinación que podría calificarse, cuanto menos, de temeraria.

Siguiendo con la frase de Weber, además del ejercicio legítimo, se requiere que el Estado lo haga exclusivamente, que ejerza un monopolio. Con toda probabilidad será ésta la única ocasión en la que se permita que el Estado concentre una capacidad de ejercer presión (en este caso, hacer cumplir las normas establecidas) como una prerrogativa sobre los demás. El Estado debe ser el poseedor de ese monopolio puesto que en caso contrario no se podría asegurar una convivencia pacífica en una comunidad en la que sus miembros optaran por ejercer individualmente la violencia al considerar que sus derechos se viesen menoscabados. No obstante, que el Estado ostente dicho monopolio no le exime de ser escrupulosamente escudrińado. Por ello la imagen del justiciero en este contexto excede los límites de la legalidad y la legitimidad.

La ficción ha abordado estas cuestiones con una mayor o menor carga de profundidad ética. En el mundo del cine, un caso paradigmático podría ser Death Wish ${ }^{8}$ donde un ciudadano desencantado con las fuerzas de seguridad decide convertirse en "juez y parte" para asombro y satisfacción de su vecindario y pesadilla tanto para los criminales como para las propias fuerzas y cuerpos de seguridad. La mera existencia de dicho ciudadano vengativo refleja la inacción e inutilidad de una policía que no es capaz de realizar la tarea fundamental que tiene asignada y para la que cobra sentido la afirmación de Weber. Si la policía ya no puede protegernos, si ya no estamos a salvo, ¿̨uién nos defenderá? Por otro lado, el cómic también ha reflejado acertadamente esta figura en múltiples ocasiones. Uno de los más significados tal vez sea The Punisher

\footnotetext{
${ }^{8}$ Death Wish [El justiciero de la ciudad], dir. Michael Winner, act. Charles Bronson, Paramount Pictures, 1974.
} 
(el castigador) ${ }^{9}$ inspirado en las novelas de Don Pendelton, The Executioner. ${ }^{10}$ Uno de los aspectos que resulta especialmente inquietante del personaje, no es tanto su comportamiento al margen de la ley (algo que queda claro a lo largo de sus aventuras) sino la facilidad con la que el lector puede llegar a empatizar con él hasta el punto de no desear que las fuerzas del orden lo eliminen.

\section{JUSTICIA, ¿PARA QUIÉN? El JUSTICIERO COMO LÍDER CARISMÁTICO}

Ante esta situación, ¿qué sentido cabe darle al concepto justicia? ¿Como equidad? Hay una acepción en el diccionario de la Real Academia Espańola de la lengua que refiere el término JUSTICIA como "conjunto de todas las virtudes, por el que es bueno quien las tiene". ${ }^{11}$ Desde esta perspectiva, habría que aceptar el hecho de que un justiciero no posee todas las virtudes pues un individuo virtuoso de verdad, sería respetuoso con la ley y la autoridad establecidas. ¿¿De qué justicia estamos hablando? Hacer un profundo análisis histórico del término nos llevaría a alejarnos de la cuestión central del artículo. Baste decir que a lo largo de la historia de la humanidad, hemos visto múltiples ejemplos en los que un personaje al margen del gobierno constituido se ha elevado por encima de las convenciones (más o menos justas) para simbolizar la lucha contra la tiránica opresión del mal dirigente.

Qué duda cabe que en ocasiones, y por ver la cuestión desde otra perspectiva, el gobernante ha tratado de ser un líder carismático al que seguir y en el que el pueblo pudiera reconocerse, convirtiéndolo así en alguien inspirador. En ocasiones lograr dicha consideración para este tipo de autoridad ha requerido, por así decirlo, de ciertos atajos morales. Uno de los máximos exponentes de esta concepción lo encontramos en el realismo político de El príncipe: “[...] porque un hombre que quiera hacer en todos los puntos profesión de bueno, labrará necesariamente su ruina entre tantos que no lo son. Por todo ello es ne-

${ }^{9}$ The Punisher es un personaje que representa al clásico antihéroe desencantado con la ley y la sociedad corruptas y que atormenta a los criminales bajo un estricto código de conducta moral que sobrepasa claramente todos los límites legales convirtiéndose en un genuino justiciero. Hizo su primera aparición en el número 129 de la revista The Amazing Spider-Man en 1974. Como dato curioso, cabe observar que fue el mismo año en el que se estrenó la película Death Wish lo cual ofrece una idea de la imagen que se tenía del justiciero en la época. Cabe recordar que otro justiciero como el policía de ficción Harry Callahan interpretado por el actor Clint Eastwood, hizo su aparición en las pantallas de cine también en la década de los 70; década abonada para este modelo de antihéroe de moral cuestionable.

${ }^{10}$ Howe, Sean, Marvel Comics: La historia jamás contada, Girona: Panini Comics, p. 141.

${ }^{11}$ DRAE, 21 a edición, tomo II, $4^{\text {a }}$ entrada, p. 1215. 
cesario a un príncipe, si se quiere mantener, que aprenda a poder ser no bueno y a usar o no usar de esta capacidad en función de la necesidad". ${ }^{12}$

Aquí radica uno de los problemas que pueden llevar a instaurar un justiciero en una comunidad. Un líder carismático, ¿debería ser una persona inspiradora? ¿Un ejemplo a seguir? ¿Un referente? Deseamos que nuestros líderes nos representen, que solucionen nuestros problemas, no que los creen. Gestionen nuestros recursos de la forma más eficaz y eficiente posibles y hagan de nuestro mundo un lugar más seguro en el que vivir. Una utopía deliciosa, pero utopía al fin y al cabo.

Y el modelo que aparece en El príncipe difícilmente parecería estar dando respuesta a esas necesidades sociales. Más bien al contrario; facilitan una figura ajena a los códigos de comportamiento aceptables desde una perspectiva ética. No debería ser calificada como una exigencia fuera de lugar el demandar a los gobernantes estar en posesión de unas virtudes que les hicieran ser merecedores de la confianza por parte de los gobernados. Si por el contrario acaban olvidándose de su papel de servidores públicos y defensores de los intereses generales, entonces no podemos luego extrañarnos de que aparezca alguien contrario al orden establecido.

\subsection{Legitimidad del héroe vs. legitimidad del justiciero}

En el planteamiento clásico de Weber sobre los diferentes tipos de legitimidad (a saber, legitimidad carismática, tradicional y racional), ${ }^{13}$ el héroe claramente se ubicaría en la legitimidad racional. No son necesariamente incompatibles entre sí pero en caso de tener que apostar por uno de los modelos, el que se fundamenta en el imperio de la ley, será, a priori, el acertado. La legitimidad que se basa en las tradiciones, la legitimidad "del eterno ayer" puede ser tanto o más reprobable como la apuesta por un modelo sustentado en el carisma del líder. ¿Serían aceptables todas las tradiciones per se? Evidentemente no. Máxime cuando dichas tradiciones pudieran ser fruto de la imposición de quien se erige como líder omnipotente.

Merece la pena volver de nuevo a las reflexiones que plantea Raymond Aron en la introducción a El político y el cientifico de Weber en relación a este líder carismático:

Imaginaba a los mejores de entre ellos (hombres políticos) revestidos de una especie de autoridad carismática. Es muy cierto que las democracias están perpetuamente amenazadas por la decadencia que entrańan el anonimato de los

${ }^{12}$ Maquiavelo, Nicolás, El principe, cap. XV, Madrid: Alianza Editorial, 1995, p. 83.

${ }^{13}$ WeBer, El politico y el cientifico, p. 84. 
poderes, la mediocridad de los dirigentes y la pasividad de las masas sin espíritu. En circunstancias trágicas cuando está en juego la vida de la nación o la Constitución ha de ser restaurada, los pueblos desean seguir a un hombre al mismo tiempo que obedecer a las leyes. [...] En los momentos críticos, los regímenes vivos hacen surgir a las personas capaces de salvarlos. En las épocas tranquilas, los jefes de la democracia son administradores honrados, a veces buenos organizadores y, más frecuentemente, simples conciliadores. El hecho de que tengan también la amplitud de visión, la clarividencia y la pasión lúcida de los grandes hombres de estado constituye un feliz azar con el que, razonablemente, no puede contarse. ${ }^{14}$

En momentos puntuales de la historia tal vez haya podido ser razonable una figura que se eleve, debido a sus características personales, por encima del resto. En ese sentido un líder carismático puede haber funcionado como revulsivo. No obstante, el líder carismático no tiene por qué ser considerado un líder democrático. El carisma que pueda poseer un individuo no le hace depositario de las cualidades exigidas para ser un buen gobernante. Es carismático, por ejemplo, el líder de una secta y no es considerado precisamente digno de loa. Podemos encontrar ejemplos de líderes que apelando a ese carisma han sido capaces de manipular, influenciar, someter a la población en aras de una pretendida "tierra prometida" que, desafortunadamente, no ha llegado. En ese sentido, sin ánimo de polemizar, se podría citar el ejemplo de la Cuba post-Batista donde la dictadura de éste, dejó paso a la utopía de la revolución encarnada por el carismático Fidel Castro. Una esperanza que décadas después tampoco se puede decir que se haya materializado en una mejora real en la calidad de vida de la isla.

También fue carismático, tal vez uno de los líderes más inspiradores de la historia reciente, el presidente John F. Kennedy. Presidente al frente de un país ligado a una edulcorada visión de la década de los 60 como una suerte de "Camelot de cuento de hadas". En cualquier caso, un líder cuyo legado, décadas más tarde, continúa ejerciendo una fuerte atracción y una capacidad de inspirar a generaciones futuras.

Basten estos ejemplos para poner de relieve que efectivamente un líder carismático puede ser inspirador. Sin embargo, la buena voluntad de un líder no puede ser el elemento definitorio de éste. Habida cuenta de que no necesariamente su proceder estará orientado en una dirección proclive a la democracia per se. Cuando ese carisma se pone al servicio de buenas acciones, de un desarrollo social justo y democrático que garantice los derechos fundamentales y en definitiva, mejore la vida de las personas, es, desde luego, deseable. En

${ }^{14}$ Weber, El político y el cientifico, p. 44. 
caso contrario, un líder carismático con una vocación desviada respecto de la democracia, llevaría a un claro abuso y perversión del poder. De las reflexiones que se suscitan, se podría entrever que las circunstancias hacen al justiciero. Ante la dicotomía sobre si éste nace o se hace, bien se podría afirmar al hilo de los planteamientos anteriores que efectivamente se hace. Surge en un momento concreto motivado por unas circunstancias determinadas. $Y$ no es, en absoluto, una situación ni exagerada ni imaginativa ni mucho menos alejada de la realidad.

El ser humano tiende a dar cumplimiento a unas necesidades esenciales. Cuando las necesidades de seguridad y protección, que diría Maslow, no son satisfechas, entramos en una dinámica de ansiedad, frustración, inseguridad, incertidumbre... y ante esa situación no es excesivo considerar a un justiciero carismático (de nuevo el carisma como elemento que justifica su comportamiento ante la sociedad y pueda ser legitimado por ésta) que restaure dichas necesidades insatisfechas. De hecho, en 2016 tuvo una cierta repercusión mediática la historia de un justiciero en México que se enfrentó a cuatro ladrones que robaron en un autobús. ${ }^{15} \mathrm{El}$ anónimo viajero, al parecer se levantó y disparó a los cuatro ladrones causándoles la muerte. Devolvió las pertenencias sustraídas a los propietarios, bajó del autobús y desapareció. Para los pasajeros del autobús había sido obra de un héroe. Para la policía, no. Nadie lo identificaba, nadie afirmaba ser capaz de describirlo o reconocerlo. Qué pudo motivar la reacción de dicho pasajero o incluso la reacción de los demás pasajeros quienes no solo asistieron impasibles al terrible desenlace sino que no dudaron en defender y justificar tal acción, es algo que desde un punto de vista ético merece ser considerado. Lo cierto es que la vulneración de la ley abre unos interrogantes cuanto menos, inquietantes.

Sirva este caso para valorar que, efectivamente en una sociedad donde confluyen variables diversas como la violencia, la corrupción, la inestabilidad, etc., tal vez se pueda estar promoviendo consciente o inconscientemente la llegada de un vengador. Alguien que ante la inacción de los considerados "representantes naturales" de la ley y el orden, desempeñe, sobrepasando la legalidad, una función que en modo alguno se le debe atribuir en el marco de un Estado democrático.

Ante ese posible escenario, debe exigirse la legitimidad racional. Aquella que se fundamenta en el imperio de la ley. En la aceptación de las reglas fijadas, consensuadas por la población en virtud del sufragio y la elección de representantes. Un modelo, el de la democracia representativa, que se constituye como elemento garantista para una legitimidad justa. $\mathrm{Y}$ aunque los diferentes

${ }^{15}$ Martínez Ahrens, Jan, "El misterio del justiciero del autobús sacude México", El País, http://internacional.elpais.com/internacional/2016/11/04/mexico/1478223570_248293.html 7 nov. 2016.11 nov. 2016. 
tipos de legitimidad puedan coincidir en una misma figura, lo verdaderamente importante es que la racionalidad, como si del auriga de Platón se tratara, se imponga sobre cualesquiera otras consideraciones para evitar, precisamente, la aparición de un sujeto que se arrogue para sí un poder que no le corresponde legítimamente. Y para hablar de un marco auténticamente democrático, dicha democracia debe ligarse intrínsecamente a la libertad. Libertad auspiciada y limitada por la ley. Pero por una ley justa. De esto modo, no existirán argumentos que puedan respaldar las tesis de un vigilante ni será posible hallar ningún resquicio dentro del marco de la ley que abone el terreno para la justificación del mismo. Cabe aquí recordar las palabras de Montesquieu al respecto cuando afirma que:

Es cierto que en las democracias parece que el pueblo hace lo que quiere; pero la libertad política no consiste en hacer lo que uno quiera. En un Estado, es decir, en una sociedad en la que hay leyes, la libertad solo puede consistir en poder hacer lo que se debe querer y en no estar obligado a hacer lo que no se debe querer.

Hay que tomar conciencia de lo que es la independencia y de lo que es la libertad. La libertad es el derecho de hacer todo lo que las leyes permiten, de modo que si un ciudadano pudiera hacer lo que las leyes prohíben, ya no habría libertad, pues los demás tendrían igualmente esta facultad. ${ }^{16}$

No hay aquí una visión ingenua o falta de realismo. En ocasiones, las leyes se transgreden. No vivimos en un modelo utópico pero el régimen democrático en el que desarrollamos nuestra cotidianeidad es, a falta de algo mejor, lo que tenemos ahora mismo y convendría cuidarlo o, parafraseando a Churchill, el menos malo de los regímenes políticos. Bien es cierto que, pese a todo, el sistema democrático no es ni mucho menos perfecto. Por ello precisamente es vital mantenerse alerta y expectante ante los posibles abusos del poder para denunciarlos y, llegado el caso, incluso desobedecerlos al modo como plantea Thoreau:

Hay leyes injustas. ¿Nos contentaremos con obedecerlas o intentaremos corregirlas y las obedeceremos hasta conseguirlo? ¿O las transgrediremos desde ahora mismo? Bajo un gobierno como este nuestro, muchos creen que deben esperar hasta convencer a la mayoría de la necesidad de alterarlo. Creen que si opusieran resistencia el remedio sería peor que la enfermedad. [...] Bajo un gobierno que encarcela a alguien injustamente, el lugar que debe ocupar el justo es también la prisión. ${ }^{17}$

${ }^{16}$ Montesquieu, Del espiritu de las leyes, Madrid: Tecnos, 2002, p. 106.

${ }^{17}$ Thoreau, Henry D., Desobediencia civil, Madrid: Tecnos, 2004, p. 40. 
El conflicto aparece cuando desde el seno del propio gobierno legitimado no se hace lo suficiente y acaba surgiendo inevitablemente un "vigilante" externo al sistema. Llegados a ese punto se abre un camino de incierto resultado.

\subsection{Cuando el sistema falla}

Una situación sociopolítica y económica injusta presupone el caldo de cultivo para que pueda instalarse alguien ajeno al sistema. Éste es el justiciero. Pero choca frontalmente con la función que el Estado se tiene asignada para sí como presenta Weber. Por tanto, ¿el justiciero tiene cabida en nuestras sociedades actuales? ¿Es compatible con la democracia? El justiciero no es un héroe. Éste imparte justicia con equidad y no bordea la ley ni, mucho menos, la quebranta. Aquél hace aquello que se debe hacer para conseguir un objetivo desde una perspectiva diríamos que absolutamente maquiavélica. Pero lo suyo no es justicia, sino, en la mayoría de las ocasiones, simple venganza. El comportamiento de un justiciero aunque pudiera ser comprensible, es éticamente reprobable y desde luego, en un contexto democrático, en ningún caso justificable. Admitir su mera existencia implicaría aceptar la venganza como norma habitual de conducta alejándose por tanto de un imperativo ético al estilo kantiano e irremediablemente alejado del sentido más profundo de la dignidad humana. Principio ya no solo esencialmente democrático sino, por encima de todo, moral. Aceptar un justiciero vengador supondría reconocer que el sistema no funciona, que está viciado, que es inútil. ¿Es eso lo que se trata de dar a entender dando cabida a dicho personaje? Y lo que es más preocupante para una sociedad democrática, ¿es lo que se desea? Habría que tener mucho cuidado con abrir la caja de Pandora, puesto que una vez abierta, no hay vuelta atrás. Los males se han escapado. En el momento en que transigimos con una "justicia” paralela a la legalidad vigente, ¿quién nos garantiza su correcta actuación?

Cuando el sistema falla, el justiciero puede ser un revulsivo, una ¿̨necesaria? visión contraria al poder establecido. Pone en jaque a la autoridad promoviendo con su acción una especie de desobediencia civil al establishment. Pero esta situación, sin pretender justificarla, solo puede ser entendida desde la premisa inicial del argumento: cuando falla el sistema. En cualquier caso, no es un argumento con el suficiente peso para poder aceptar una figura al margen de la ley. Tan simple como eso. Suele ser considerado como positivo la existencia de referentes morales. Pero el justiciero no puede erigirse en uno de ellos. Y aquí surge un problema de impredecibles consecuencias. Las referencias morales, los ideales de vida representan algo positivo, algo inspirador. Una influencia adecuada que desde pequeńos, en la familia, en la escuela o en la sociedad vamos recibiendo. Como elemento motivador, vamos proyectando reflejos de 
esos estandartes éticos. Pero claro, siempre y cuando dichas referencias sean las adecuadas. ¿Es adecuado el mensaje que subyace bajo la mentalidad del justiciero? ¿Es la venganza un valor a transmitir? En definitiva, ¿qué referentes queremos? ¿En qué medida no sería arriesgada la apuesta por alguien que decide qué es justo, correcto o equitativo? Y en cualquier caso, ¿`cómo se puede llegar a controlar? Porque al fin y al cabo, el problema no radica en la aparición de una voz que despierte la conciencia de la comunidad. Esto es algo meritorio. El verdadero problema reside en su mera aceptación. Porque una vez "liberado", su control y posterior anulación se convierte en tarea harto complicada. Cerrar nuevamente la caja de Pandora se presenta como una empresa titánica.

\section{3. ¿QUÉ HÉROE? ¿QUÉ JUSTICIERO?}

Como señala Luis Gil en la presentación a El mito del héroe de Bauzá:

La figura del héroe, como la del santo, más que mitos son arquetipos culturales heredados de un pasado remoto en los que la realidad histórica y los embellecimientos de la imaginación se han imbricado inextricablemente. Como tales arquetipos, sirven de ideas-motrices desde el momento en que una sociedad los toma como modelos de conducta. ${ }^{18}$

Esta es la cuestión capital: cuando la sociedad toma al héroe como modelo de conducta, como referente en el que verse reflejado, no vale cualquier tipo de héroe. No todos pueden ser héroes. Por tanto es crucial plantearse qué representación del héroe se pretende adoptar como referente. La figura del héroe queda muchas veces ensombrecida por su propia leyenda. Un héroe es un ídolo que queda mitificado. Las más de las veces el héroe asciende a esta categoría tras desaparecer con la muerte. El mito del héroe desempeña una función social. Es un personaje aglutinador. Puede estar llamado a representar los ideales más elevados de una sociedad pero para ello tiene que convertirse en un verdadero estandarte. En un auténtico referente. En palabras de Bauzá, "lo que más se ha valorado en los héroes es el móvil ético de su acción, fundado éste en un principio de solidaridad y justicia social". ${ }^{19} \mathrm{El}$ héroe ha de ser un acicate hasta el punto de desear emular sus acciones. El marco de acción del héroe está bien delimitado. No es posible un infinito abanico de posibilidades. Su proceder, de alguna manera, queda sujeto y condicionado por la visión que se tiene de él.

${ }^{18}$ GIL, Luis, Introducción a BAUZÁ, H. F., El mito del héroe: Morfología y semántica de la figura heroica, Buenos Aires: F.C.E., 2007, p. ix.

${ }^{19}$ BAuzÁ, El mito del héroe: Morfología y semántica de la figura heroica, p. 5. 
Es la imagen que ofrece Eco cuando destaca al héroe como alguien que "debe ser un arquetipo, la suma y compendio de determinadas aspiraciones colectivas, y por tanto debe inmovilizarse en una fijeza emblemática que lo haga fácilmente reconocible". ${ }^{20}$ Bajo esta óptica, el héroe representa a alguien cuya actuación podría calificarse como previsible, invariable y estática. Se sabe qué se espera de él y se es exigente con él porque "es profundamente bueno, moral, subordinado a las leyes naturales y civiles, por lo que es legítimo que emplee sus poderes con fines benéficos". ${ }^{21}$ Es importante esta cuestión dado que se señala el camino que debe seguir el héroe. Sus poderes podrán ser legítimamente utilizados en la medida que de ellos se deriven beneficios para la población. Ya sea para garantizar su seguridad, otorgar protección o cualquier otra necesidad. Además el héroe por antonomasia es virtuoso. Para Savater, "el héroe no solo hace lo que está bien, sino que ejemplifica por qué está bien hacerlo"22 y con ello convierte en valioso el comportamiento virtuoso. No en la virtud en sí misma sino en el propio ejecutante, esto es, el héroe. Porque allí donde otros fracasan, afirma Savater, el héroe hará posible el "más difícil todavía" triunfará ante las adversidades porque quiere y porque puede.

En el extremo opuesto se sitúa el antihéroe, el vigilante, el vengador, el justiciero. Diversas maneras de referirse a la misma idea: un fuera de la ley. Alguien que tratará de imponer su forma de ver la justicia de un modo poco ortodoxo y que, aun compartiendo elementos con el héroe, fácilmente parece desviarse del ideal heroico. Nuevamente Eco establece los rasgos propios de este dominador al otorgarle una manera de proceder alejada radicalmente de la esencia del héroe: [...] "utiliza métodos antisociales, con arreglo a la ley del talión; el fin justifica los medios, y la justicia debe salir triunfante aunque sea a navajazos" ${ }^{23} \mathrm{La}$ caracterización que se hace de este personaje no invita a pensar en la bondad de sus acciones y, lo que es peor, que dicha conducta suponga una escalada en la que se acabe subvirtiendo el orden legítimamente reconocido abriéndose ante sí un escenario alarmante. Con respecto a personajes de esta índole, Eco advierte:

Y como la sociedad no reconoce esa necesidad de justicia y nunca comprendería sus propósitos, habrán de perseguirlos e intentar realizarlos en contra de la sociedad y de las leyes. Para poder hacerlo deberán estar dotados de cualidades excepcionales y poseer una fuerza carismática que legitime su decisión aparentemente subversiva. ${ }^{24}$

${ }^{20}$ Eco, Umberto, Apocalípticos e integrados, Barcelona: De Bolsillo, 2016, p. 270.

${ }^{21}$ Eco, Apocalipticos e integrados, p. 297.

${ }^{22}$ Savater, Fernando, La tarea del héroe, Madrid: Taurus, 1983, p. 113.

${ }^{23}$ Eco, Umberto, El superhombre de masas, Barcelona: De Bolsillo, 2016, p. 94.

${ }^{24}$ Eco, El superhombre de masas, p. 104. 
Resulta inevitable acordarse del ideal nietzscheano de superhombre. Parecería que este antihéroe aquí propuesto fuera un reflejo de la moral de señores fuertes y orgullosos frente al héroe clásico que bien podría simbolizar una moral de esclavos en la que la amabilidad o la compasión fuesen valores esenciales. ${ }^{25}$

\subsection{La ética como convicción y la ética como responsabilidad}

Tanto el héroe como el justiciero podrían enmarcarse en alguno de los dos modos de entender la ética que plantea Weber: la ética como convicción y la ética como responsabilidad. En líneas generales podría asociarse al héroe con la ética de la responsabilidad y al justiciero con la ética de la convicción. Pero es una analogía algo simplista. En cualquier caso, son dos propuestas que Weber presenta en un primer momento como antagonistas (distintos entre sí e irremediablemente opuestos) hasta el punto de señalar con rotundidad:

No es posible meter en el mismo saco la ética de la convicción y la ética de la responsabilidad, del mismo modo que no es posible decretar éticamente qué fines pueden santificar tales o cuales medios, cuando se quiere hacer alguna concesión a este principio. ${ }^{26}$

Pero no sería correcto hablar respecto a esta distinción, de un posicionamiento claramente maniqueo. A grandes rasgos, el héroe asume la ética de la responsabilidad. Las consecuencias de sus acciones son asumidas con madurez. Por el contrario, la ética de la convicción se centra más en los actos al margen de las consecuencias. Para Weber aquel sujeto con vocación de servicio ${ }^{27}$ debe poseer tres elementos básicos: pasión, sentido de la responsabilidad y mesura (Weber 20 I 5, 151). El héroe podría presentar estas cualidades. ¿También el justiciero? En un comportamiento ligado a la ética de la convicción podríamos hallar una auténtica pasión en el desempeño de la tarea de vigilancia por parte del justiciero. Pero difícilmente se podría acreditar un sentido de la responsabilidad (a no ser que se aceptase un sentido "distorsionado" de la misma) y mucho menos mesura en su proceder. Para el justiciero, la convicción de unos principios puede hacer que se acabe alejando de las nobles motivaciones que sustentaban tales principios. Sin embargo para el héroe, la ética de la responsabilidad sí va asociada a un apasionado altruismo en su acción además de un

\footnotetext{
${ }^{25}$ Esta idea de la moral de señores y la moral de esclavos aparece en buena parte de la obra de Nietzsche. Especialmente en Más allá del bien y del mal o La genealogía de la moral.

${ }^{26}$ Weber, El politico y el cientifico, p. 164.

${ }^{27}$ Para Weber; el político, pero en el contexto que nos ocupa, caben perfectamente tanto las figuras del héroe como la del justiciero pues, en última instancia, ambos tratan a su manera de ofrecer un servicio a la comunidad aunque con métodos diametralmente opuestos.
} 
claro comedimiento en la forma en que lleva a cabo dicha acción. Por decirlo de otro modo, el héroe asume las consecuencias de sus actos. El justiciero no. Y a pesar de esa distinción, el propio Weber finaliza su reflexión al respecto afirmando la complementariedad de ambos tipos de ética: "[...] la ética de la responsabilidad y la ética de la convicción no son términos absolutamente opuestos, sino elementos complementarios que han de concurrir para formar al hombre auténtico, al hombre que puede tener 'vocación política'” ${ }^{28}$

\section{LIBERTAD VS. SEGURIDAD: DICOTOMÍA NO SUPERADA}

Parte del debate en torno al justiciero hay que situarlo en la clásica disyunción entre preponderar la libertad o la seguridad en un Estado. Las disquisiciones éticas se enfrentan al dilema de aceptar un modelo donde se nos garanticen unos valores a cambio de la renuncia a otros. Ese es el sentido que se plantea desde la visión hobbesiana en relación a un modelo de estado que garantiza la seguridad de la ciudadanía a costa de la merma de libertades civiles esenciales. No es una cuestión menor ni mucho menos extemporánea. Citaré un ejemplo de esta dicotomía y cómo se ve plasmada en el mundo del cómic. Los atentados de las torres gemelas de Nueva York en septiembre de 2001 tuvieron como consecuencia (al margen de las pérdidas humanas, claro) el sentimiento de desprotección, impotencia e inseguridad que llevaron a la justificación y posterior aprobación de la patriot act. ${ }^{29}$ Esta ley patriótica pretendía salvaguardar la seguridad del pueblo estadounidense. Se estableció de forma implícita que era necesario "pagar un peaje" por la seguridad de la comunidad para seguir garantizando el american way of life.

En el otro extremo, tras los atentados en Madrid de marzo de 2004, no se planteó una medida similar para España hasta el punto de crear una ley que expresamente restringiera derechos de la población. De manera un tanto simple, se podría decir que EE.UU. apostó por la seguridad en detrimento de las libertades civiles. En España esta medida no se produjo. Sirva este ejemplo para valorar cómo la actuación en un sentido u otro, ante un determinado acontecimiento extraordinario puede llevar a remover las conciencias hasta el punto de poner en tela de juicio el orden democrático establecido y los valores comunes compartidos.

La novela gráfica de Mark Millar, Civil War, ${ }^{30}$ refleja muy claramente esta confrontación entre libertad y seguridad. El argumento gira en torno a un

${ }^{28}$ WeBer, El político y el científico, p. 173.

${ }^{29}$ La ley patriótica fue aprobada tanto en la Cámara de Representantes como en el Senado y promulgada en octubre de 2001 por el entonces presidente George W. Bush.

${ }^{30}$ Millar, Mark y Mcniven, Steve, Civil War, Barcelona: Marvel Deluxe. Panini Comics, 2010 . 
episodio desafortunado provocado por los poderes de un superhéroe (Nitro) que lleva a la creación por parte del gobierno de un acta de registro y control de superhéroes (sucedáneo de la patriot act americana) en virtud de la cual los superhéroes deberán estar registrados con su identidad real y los poderes que poseen y trabajar bajo las órdenes del gobierno. A partir de este momento se entabla una persecución entre superhéroes alineados en dos bandos claramente diferenciados capitaneados por dos personajes paradigmáticos: Iron Man, defensor del acta de registro y que acepta las medidas del gobierno en pos de la seguridad (no deja de ser curioso que el alter ego de Iron Man, Tony Stark, sea un empresario e ingeniero multimillonario gracias a la creación y venta de armamento militar) y por otra parte el Capitán América, paladín de la libertad. Todo un icono que invita a la reflexión. ${ }^{31}$

\section{Justicieros vs. HÉroes de CómiC}

El mundo del cómic (o su posterior traslación al cine) describe un contexto donde resulta difícil trazar la línea divisoria entre la verdadera justicia y el rol del justiciero. Entre la legitimidad de la ley y la aceptación social del vengador. A lo largo de la historia del cómic de héroes y/o superhéroes, hay múltiples referencias a personajes que han ido apareciendo o han sido reinterpretados como justicieros opuestos al sistema.

De entre los diferentes cómics que han planteado esta cuestión, tal vez uno de los más significativos sea el cómic de Alan Moore y David Lloyd, $V$ de Vendetta. ${ }^{32}$ En una distópica Inglaterra, la justicia idealizada por $\mathrm{V}$, ha dejado paso a un régimen totalitario. El protagonista se verá en la obligación de asumir un rol anárquico para enfrentarse a esa tiranía totalitaria. Para V, la justicia es inútil sin libertad y en el contexto que le toca vivir, la libertad brilla por su ausencia y por tanto V se verá abocado a imponer "su" justicia. $\mathrm{V}$ de Vendetta personifica uno de los riesgos más grandes que pueden surgir en relación a la idea del justiciero. En una sociedad democrática, el justiciero no tiene cabida. Pero en una sociedad totalitaria, este personaje, de manera un tanto torticera, se reviste a sí mismo de una pretendida legitimación y ahí radica precisamente el problema. Luchar contra ese modelo totalitario debería plantearse con el objetivo de cambiar dicho modelo por una legítima democracia. Pero no desde la perspectiva de un fuera de la ley porque si se

${ }^{31}$ En 2016 se estrenó la película Capitán América: Civil War en la que se presenta una adaptación de la novela gráfica Civil War con bastantes licencias sobre el original pero en la que se evidencia el debate no resuelto entre libertad y seguridad.

${ }^{32} V$ de Vendetta, Alan Moore y David Lloyd, 6a edición, Barcelona: ECC Ediciones, 2015. 
actúa en este sentido, no puede luego sorprender la aparición de individuos como el propio V o como el justiciero de la ciudad Paul Kersey. ${ }^{33}$

Lo inquietante con respecto a esta idea es que, pese a ser algo mostrado en una novela gráfica, lo cierto es que episodios de este tipo, con mayor o menor grado de exageración, suceden. Según lo dicho, se podría incluso encontrar un paralelismo entre la merma de confianza en las instituciones que nos gobiernan y la aparición de movimientos sociales que canalizan un descontento hacia la política constituyéndose en formaciones al margen del sistema y de los cauces tradicionalmente considerados. Esta podría ser una posible explicación (de entre otras muchas pero que no es objeto de análisis en este artículo) del auge de estos movimientos en países de Europa, como Francia, Grecia, Italia, Austria, Alemania, España o también en Estados Unidos con la elección de un presidente ajeno al mundo de la política y aupado en base a un discurso que podría tildarse de populista y demagógico. ¿Por qué van teniendo más relevancia movimientos sociopolíticos tan alejados de la tradicional visión de la política? De algún modo, la mirada que proyectan los cómics no está tan alejada de la realidad a la vista del contexto geopolítico actual. De hecho, los cómics no son más que un reflejo de la realidad con la que les toca coexistir. Una imagen (a veces, escalofriantemente fiel) de la sociedad y del momento político en que se enmarcan.

Parece claro por tanto que, en la medida en que las necesidades básicas no se vean satisfechas y las instituciones no sean capaces de darles cumplimiento, se abonará el terreno para que una figura crítica aparezca para tratar de doblegar al injusto poder establecido. Los factores que la originan son diversos; algunos han sido señalados ya. Pero cuando el Estado no es capaz de ofrecer una respuesta satisfactoria a las demandas sociales, entonces es razonable pensar que se tenderá a buscar "en otra dirección". Históricamente las desigualdades sociales han lastrado un verdadero progreso y desarrollo de las naciones. $\mathrm{Al}$ mismo tiempo han posibilitado la aparición de modelos anti-sistema, contestatarios... llámense como se quiera. Cuando el Estado no es capaz de garantizar lo que nos es más íntimamente querido (principalmente, nuestros derechos individuales empezando por la seguridad) entonces pierde su legitimidad y en consecuencia, volviendo a Weber, el monopolio del uso legítimo de la violencia se desvanece. $\mathrm{Y}$ en ausencia de un poder claramente tendente al bien común, puede surgir una figura vengativa que distorsione el objetivo principal y se arrogue el derecho de ejercer motu proprio la potestad atribuida de iure únicamente al Estado. Por el contrario, será en tales circunstancias cuando el verdadero héroe y los valores que éste encarna cobrarán, si cabe, mayor sentido.

${ }^{33}$ Ver nota 8. Paul Kersey es el personaje que interpreta el actor Charles Bronson en la película citada. 
Las circunstancias excepcionales por tanto hacen al justiciero. El conflicto aparece cuando, aceptada la premisa de la supuesta ineptitud del Estado para garantizar unos derechos básicos, la alternativa puede llegar a ser tanto o más reaccionaria. Tal es así que un movimiento errático puede convertirse no tanto en solución sino en el inicio de un caos de devastadoras proporciones. Los modelos totalitarios son un claro ejemplo. Cuando los valores morales que dan sentido a un modelo de sociedad democrática son eliminados, se instaura una peligrosa inanidad de la que ya advierte Hannah Arendt, "el totalitarismo busca no la dominación despótica de los hombres, sino un sistema en el que los hombres sean superfluos". ${ }^{34} \mathrm{Y}$ cuando este enfoque totalitario triunfa, se infiltra en todas las esferas de la colectividad una mentalidad proclive a erosionar los pilares mismos de la convivencia. De una convivencia fundamentada en la igualdad, la tolerancia, el respeto y, desde luego, la justicia. Un sistema corrompido rara vez ofrecerá una solución para restaurar ese modelo de convivencia deseable porque además, la propaganda totalitaria consigue "adormecer" primero y deshumanizar a la gente hasta hacer que desaparezca incluso un mero anhelo de libertad y suele desafortunadamente, tener éxito en su empeño. Y esta deshumanización, cuyo máximo exponente lo encarnaron los campos de exterminio, lleva a una podredumbre moral por lo que representa de indigno.

No caben pues equidistancias entre el justiciero y el héroe tradicional. Ambos pueden ser vistos como revulsivos para "poner orden" en una sociedad desnortada. Pero los medios que utilicen uno u otro definirán a los propios personajes y los posteriores acontecimientos que se deriven de sus acciones. El justiciero no puede erigirse como un sustituto que imponga su propia concepción de la justicia. El justiciero, y esto es capital, se sitúa al margen de la ley. Es más; se ubica por encima de ella hasta el punto de arrogarse el derecho de ejercerla a su merced. Por eso es de vital importancia que "la violencia legítima" esté sostenida por un único actor, el Estado, y que dichas atribuciones sean consentidas y aceptadas libremente por la sociedad civil. $Y$ en este sentido, para el mundo del cómic la figura del héroe tradicional no es cuestionable puesto que los intereses que defiende, los métodos que utiliza y el fin que persigue están siempre orientados por unos valores dentro de un marco de democracia ajenos al justiciero.

Los cómics de superhéroes han sido un medio eficaz para presentar un retrato idealizado y romántico del héroe capaz de luchar en pos de un ideal por encima de los propios intereses. El prototipo de aquél que es capaz de sacrificarse por unos principios nobles. Que es capaz de posponer su felicidad o sus intereses particulares por un bien mayor. Tal podría ser el caso de arquetipos

${ }^{34}$ Arendt, Hannah, Los orígenes del Totalitarismo, $3^{\text {a }}$ reimpresión, Madrid: Alianza Editorial, 2009, p. 613. 
como Superman. Este modelo de héroe no es un justiciero. Esos personajes ejemplifican ese anhelo de justicia, de paz y prosperidad para los pueblos pero nunca superando los límites que marcan las leyes. Superman, por ejemplo, es un dechado de virtudes. No actúa inadecuadamente. Superman ni siquiera miente. Este héroe sería la representación del modelo que plantea Luis Alberto de Cuenca cuando señala que "el héroe siempre dice la verdad. Odia la mentira como algo infamante y defiende la franqueza con entusiasmo. Cumple con su palabra, se mantiene en lo que ha prometido. Una palabra, un hombre". ${ }^{35}$ Podría asemejarse al paradigma que en el mundo del cine ha interpretado en múltiples ocasiones el actor James Stewart; un caballero sin espada. ${ }^{36} \mathrm{Y}$ en el caso de Superman, un caballero con capa.

En el otro extremo, se podría situar a Batman, con especial énfasis el Batman reinterpretado por Frank Miller ${ }^{37}$ en los cómics de mitad de los años 80 donde la moral del personaje es ambigua y refleja más la encarnación del justiciero que de un fiel cumplidor de la legalidad. Es ese patrón el que pervive como el peligroso referente moral en la lucha contra la opresión, la injusticia y la corrupción. Y es peligroso por cuanto que al abuso de la ley se debe responder con más ley. O dicho con otras palabras: la desobediencia civil puede estar justificada cuando existen injusticias pero hay que ir con mucho cuidado cuando se buscan subterfugios para tratar de reinstaurar el orden pues tal y como advierte Luther King:

[...] la paz no puede ser simplemente un objetivo distante, sino que son los medios con cuya utilización llegaremos a aquel objetivo. Para alcanzar un fin pacífico, debemos emplear medios pacíficos. Y con estas palabras, como análisis final, pretendo decir que el fin y los medios deben estar en estrecha correspondencia, pues el fin ya está contenido en los medios, y finalmente, unos medios destructivos nunca podrán llevarnos hacia un fin constructivo. ${ }^{38}$

Lo cierto es que un justiciero no incorporará la justicia que realmente se necesita. Tal vez en un principio pueda asemejarse a algo parecido a la justicia, pero es una quimera. Un comportamiento personalista y egoísta enmascarado en un remedo de justicia provocado, quién sabe, si por conflictos no resueltos

${ }^{35}$ De Cuenca, Luis Alberto, El héroe y sus máscaras, Madrid: Biblioteca Mondadori, 1991, p. 19.

${ }^{36} \mathrm{Mr}$. Smith goes to Washington [Caballero sin esapda], dir. Frank Capra, act. James Stewart, Columbia Pictures, 1939.

${ }^{37}$ Batman: El regreso del caballero oscuro, Frank Miller y Klaus Janson, 4a edición. Barcelona: ECC Ediciones, 2016.

${ }^{38}$ Luther KIng, Martin, El clarín de la conciencia, 2a edición, Barcelona: Aymá S.A. Editora, 1973, p. 106. 
(tal es el caso del Batman de Frank Miller, un ejemplo de perfil psicológico al límite por traumas no superados). Estas ideas se ven reflejadas en la reinterpretación del cinematográfico Batman de esta última década. Concretamente, en la película Batman: El caballero oscuro. ${ }^{39}$ Allí, el rol del policía Jim Gordon (interpretado por el actor Gary Oldman), uno de los escasos representantes honestos que aparecen en la película y una suerte de David contra el Goliat que simboliza la corrupta ciudad de Gotham, sugiere una interesante reflexión final sobre las consecuencias de un justiciero (Batman) aceptado casi inconscientemente por la sociedad. Se trata de una conversación que mantiene el policía Jim Gordon con su propio hijo tras ser éste secuestrado a raíz de un plan del malvado Joker y rescatado al final de la película por Batman, quien en un epílogo épico huye en su batmoto convertido ya en un caballero oscuro:

—¿Por qué huye, papá?

- Porque tenemos que perseguirle.

- Pero si no ha hecho nada malo.

- Porque es el héroe que Gotham se merece, pero no el que necesita ahora mismo. Así que lo perseguiremos porque él puede resistirlo. Porque no es un héroe. Es un guardián silencioso, un protector vigilante. Un caballero oscuro.

Por épico que pueda parecer el final de la película (más bien un final made in Hollywood), el mensaje es, cuanto menos, perturbador. El comisario Gordon y con él la ciudad de Gotham como "su protegida" están aceptando y justificando a Batman, y por lo tanto esa visión casi romántica del justiciero. La legalidad se va a mantener pero a costa de mentiras. ${ }^{40}$ Son curiosas las palabras porque el rol del policía asume que la ciudad, una vez traspasada la frágil línea de la justicia, tiene un tipo de héroe que no sólo bordea la ley sino que la sobrepasa. Una nueva situación no sobrevenida sino aceptada tácitamente por la misma sociedad que en consecuencia se enfrenta al dilema de legitimar a un justiciero que, en palabras del policía, la ciudad se merece. Más bien como una especie de castigo que como un premio. Un justiciero, no un paladín de la justicia, que actúa como un revulsivo en un momento concreto, puntual y probablemente justificado por una realidad que supera lo razonable. Pero las consecuencias de su llegada pueden ser a medio o largo plazo especialmente negativas, si no devastadoras, para el tejido moral de una sociedad. Esto es debido a que si las manifestaciones de un justiciero son aclamadas y aplaudidas por la

${ }^{39}$ The Dark Knight [Batman: El caballero oscuro], dir. Christopher Nolan, act. Christian Bale y otros, Warner Bros. Pictures, 2008.

${ }^{40}$ No obstante, cabe señalar que en la tercera y última entrega de las aventuras de este cinematográfico Batman, se procede a restaurar su honor y salen a la luz los motivos que produjeron su huida y la persecución policial a la que es sometido. 
ciudadanía con una disposición acrítica, luego no puede causar extrañeza que ese "monstruo" al que se le ha sacado de la jaula no quiera volver a entrar en ella. ¿De qué manera se podrá controlar al justiciero cuando éste se encuentra a sí mismo legitimado para hacer aquello que en el acervo popular no es valorado sino como mera venganza?

\section{REFLEXIÓN FINAL: ¿QUÉ CLASE DE HÉROE? ¿NECESITAMOS HÉROES?}

Finalmente, se podría valorar si la idoneidad de un justiciero aporta más beneficios que desventajas a una comunidad. La realidad es que en la medida en que se busquen salidas que justifiquen una acción fuera de la ley estaremos poniendo las bases para el advenimiento de un modelo de Estado que será un remedo de democracia, pero no una democracia real. Es por ello que cobra tanta importancia en este contexto la "recomendación" de Platón en su obra Las leyes cuando afirma que, "es imprescindible que los hombres tengan leyes y que se sometan a ellas; sin lo cual en nada se diferenciarían de las bestias más feroces". ${ }^{41}$

La conclusión es, por tanto evidente. Para Weber el Estado ostenta el monopolio de la violencia legítima. Un justiciero sería un ejemplo de "detentador" de esa atribución que en exclusiva se arroga el Estado. Las leyes se hacen necesarias para la convivencia. Leyes justas; claro está. Lo contrario puede llevar a un fuera de la ley, a quien la bordea peligrosamente o, en el peor de los casos, la interpreta torticera e interesadamente. El verdadero héroe será el responsable de restablecer el orden y servir como acicate para una sociedad cuyos principios morales puedan haber sido menoscabados o incluso sustituidos por otros no deseados. Son en tales circunstancias, como las aquí expuestas, en las que se precisa un verdadero héroe. No un justiciero. Un adalid de la justicia, un referente que pueda ser lo suficientemente inspirador como para recordar algo tan importante como que no se deberían tomar atajos en el camino de la justicia. Nada más y nada menos.

Para ir finalizando, con respecto a la idea del héroe, una última reflexión para dejar abierto el debate. La inspiración suele ser una de las más recurrentes características inherentes al héroe. Como aprecia Castillo "los héroes han sido siempre ejemplos de comportamiento para las nuevas generaciones, a las que muestran su capacidad de entrega, de sacrificio y de superación personal" ${ }^{42} \mathrm{Sin}$ tener que estar necesariamente en desacuerdo con esta idea, podría también plantearse que el modelo a seguir considerado como auténticamente inspirador debería, sencillamente, no existir. Así de simple. La mayoría de las personas

${ }^{41}$ Platón, Las leyes, libro IX, 875a, 2a edición, Madrid: Alianza Editorial, 2014, p. 496-7.

${ }^{42}$ Castillo, Gerardo, La forja del héroe, Madrid: Ediciones Rialp, 2013, p. 9. 
podemos en un momento determinado realizar actos que bien podrían ser considerados como heroicos, como dignos de ser imitados. Episodios de la vida cotidiana que alejados del "glamour" de los héroes con capa nos acercan más a la realidad y que reflejan, probablemente mejor, la idea más objetiva y exenta de romanticismo que se le puede atribuir a un héroe. Un héroe de lo cotidiano. Como apuntan Loeb y Morris:

Entre los héroes que viven y trabajan a nuestro alrededor día a día se cuentan tanto hombres como mujeres, bomberos, policías, médicos, enfermeros, maestros. [...] Luchan por la salud, la seguridad, la excelencia y el crecimiento humanos. Son guerreros de la vida cotidiana cuyos sacrificios y acciones nobles nos benefician a todos. Sin embargo, no solemos considerar héroes a estas personas. ${ }^{43}$

Tal vez el modelo que se persigue no debería estar alejado de la realidad. Tal vez en lugar de buscar figuras inspiradoras convertidas en estándares morales (no siempre fácilmente alcanzables) sería más realista aceptar unos héroes de carne y hueso, gente normal en situaciones normales que desempeñan su tarea lo mejor posible. Según esta visión, "un héroe es cualquier individuo que realice bien su trabajo y haga una contribución mínima al bienestar público" ${ }^{44}$ Baste una imagen para poner de relieve esta última idea. En el número correspondiente a diciembre de 2001, en el cómic The Amazing Spider-man ${ }^{45}$ (Fig. 1) se hizo un sentido homenaje a las víctimas del brutal atentado de las Torres gemelas de Nueva York. En la historia que se presenta en el cómic se ve una clara apuesta por la figura del héroe ordinario. En una situación inimaginable, los superhéroes han sido incapaces de prevenir el ataque. Las consecuencias se reflejan a lo largo de toda la historia del citado cómic. Pero tal vez una de las imágenes con mayor fuerza es la vińeta que cierra el número y en la que se ven en un segundo plano a los superhéroes y en primer término a los que se convirtieron involuntariamente en los verdaderos héroes de esos días: policías, bomberos, médicos, gente anónima que dieron lo mejor de ellos mismos y que encarnaron de manera natural y espontánea pero desinteresadamente los valores que se esperan de un auténtico héroe no de un justiciero.

${ }^{43}$ Loeb, J. y Morris T., Héroes y superhéroes en Los superhéroes y la filosofía, Barcelona: Blackie Books, 2010, p. 36.

${ }^{44}$ Hook, Sidney. El héroe en la historia, Buenos Aires: Galatea - Nueva Visión, 1943, p. 169.

${ }^{45}$ Straczynsky, J. M. y Romita Jr., John, The Amazing Spider-man (Vol.2) \#36. Spiderman: los imprescindibles. Barcelona: Panini Comics, 2007. 


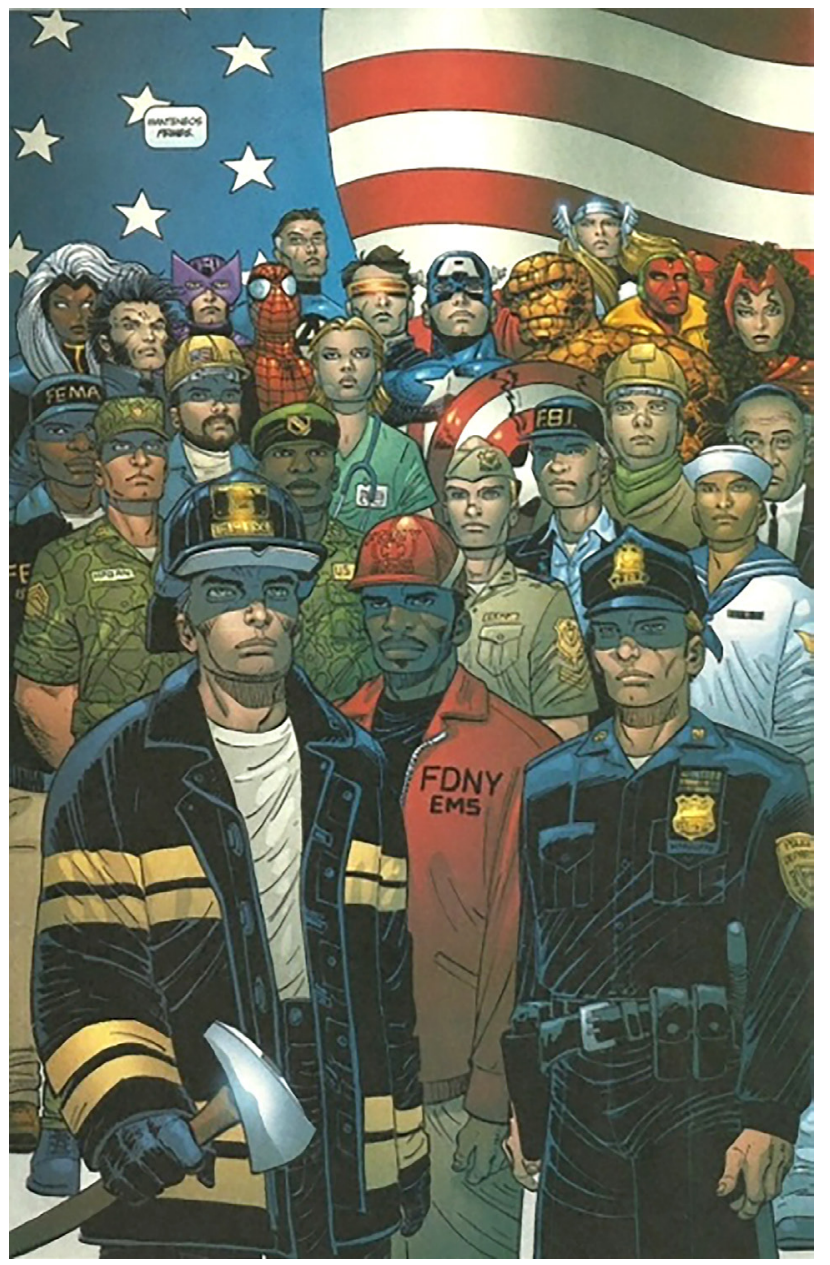

FIG. 1. Amazing Spider-Man (Vol. 2) \#36

"Un héroe no es más valiente que un hombre corriente, pero lo es cinco minutos más" Ralph Waldo Emerson 


\section{BIBLIOGRAFÍA}

Arendt, H. 2009, Los orígenes del totalitarismo, Madrid: Alianza Editorial.

BauzÁ, H. F. 2007, El mito del héroe: Morfología y semántica de la figura heroica, Buenos Aires: Fondo de Cultura Económica.

Castillo, G. 201 3, La forja del héroe, Madrid: Ediciones Rialp.

De Cuenca, L. A. I991, El héroe y sus máscaras, Madrid: Biblioteca Mondadori.

Eco, U. 2016, Apocalípticos e integrados, Barcelona: De Bolsillo.

Eco, U. 2016, El superhombre de masas, Barcelona: De Bolsillo.

Hobbes, T. 1983, Leviatan, Madrid: Editorial Sarpe.

Ноок, S. 1943, El héroe en la historia, Buenos Aires: Galatea-Nueva Visión.

Howe, S. 20 I 3, Marvel Comics: La historia jamás contada, Girona: Panini Comics.

Luther King, M. I973, El clarín de la conciencia, Barcelona: Aymá S.A.

Maquiavelo, N. 1995, El principe, Madrid: Alianza Editorial.

Montesquieu 2002, Del espiritu de las leyes, Madrid: Tecnos,.

Morris M.; Morris T. (ed.) 20 io, Los superhéroes y la filosofía, Barcelona: Blackie Books.

Nietzsche, F. 200 i, La genealogía de la moral, Madrid: Alianza Editorial.

Nietzsche, F. 2007, Más allá del bien y del mal, Madrid: Alianza Editorial.

Platón 20I 4, Las Leyes, Madrid: Alianza Editorial.

Savater, F. I983, La tarea del héroe, Madrid: Taurus.

Thoreau, H. D. 2004, Desobediencia civil, Madrid: Tecnos.

Weber, M. 20 I 5, El político y el cientifico, Madrid: Alianza Editorial.

\section{WEBGRAFÍA}

Martínez Ahrens, J. 20 i 6, "Elmisterio del justiciero del autobús sacude México": http:// internacional.elpais.com/internacional/2016/11/04/mexico/1478223570 _248293.html. El País, 7-11 nov. 
NOVELAS GRÁFICAS/CÓMICS

Conway, G.; Andru, R. 2016, The Amazing Spider-Man \#129 en Marvel Gold. El asombroso Spider-Man 6. La saga del clon, Girona: Panini Comics.

Millar, M.; McNiven, S. 2oro, Civil War, Barcelona: Marvel Deluxe. Panini Comics.

Miller, F.; Janson, K. 20I6, Batman: El regreso del caballero oscuro, Barcelona: ECC Ediciones.

Moore, A.; Lloyd, D. 201 5, V de Vendetta, Barcelona: ECC Ediciones.

Straczynsky, J. M.; Romita Jr., J. 2007, The Amazing Spider-Man (Vol.2) \#36.

Spider-man: Los imprescindibles, Barcelona: Panini Comics.

Filmografía

Death Wish [El justiciero de la ciudad], dir. Michael Winner, Paramount Pictures, I974.

Mr. Smith goes to Washington [Caballero sin espada], dir. Frank CAPra, Columbia Pictures, 1939.

The Dark Knight [Batman: El caballero oscuro], dir. Christopher Nolan, Warner Bros. Pictures, 2008.

\section{DiCCIONARIOS Y MANUALES}

Diccionario de la Real Academia Española, Madrid: Editorial Espasa-Calpe, I995. 
